\title{
ANALYSIS OF ENGINE OILS FROM FARM TRACTORS IN THE ASPECT OF THEIR CHANGE
}

\author{
Wojciech Gołębiowski ${ }^{\mathrm{a}}$, Grzegorz Zając $\mathrm{a}^{\mathrm{a}^{*}}$, Artur Wolak \\ a Department of Power Engineering and Transportation, University of Life Sciences in Lublin \\ b Department of Industrial Commodity Science, Cracow University of Economics \\ ${ }^{*}$ Corresponding author: e-mail: grzegorz.zajac@up.lublin.pl
}

\begin{tabular}{|c|c|}
\hline ARTICLE INFO & ABSTRACT \\
\hline $\begin{array}{l}\text { Article history: } \\
\text { Received: January } 2019 \\
\text { Received in the revised form: } \\
\text { February } 2019 \\
\text { Accepted: March } 2019 \\
\end{array}$ & \multirow{2}{*}{$\begin{array}{l}\text { The paper presents results of research on selected physico-chemical pa- } \\
\text { rameters of engine oils from farm tractors based on the date of their } \\
\text { change assumed by the user. } 17 \text { samples of used engine oil from farm } \\
\text { tractors of various producers and with a varied exploitation course were } \\
\text { analysed. Oils for research were collected during oil change, registering } \\
\text { the service life of oil each time. They were obtained from service points } \\
\text { that repair farm tractors in the region of Lublin Province. The studies } \\
\text { were to verify whether a decision concerning oil change taken by tractor } \\
\text { users after specific time of operation of an engine was good. Number } \\
\text { of exceedings of the threshold values of parameters of engine oil which } \\
\text { are responsible for correct lubrication were the basis for evaluation. }\end{array}$} \\
\hline $\begin{array}{l}\text { Key words: } \\
\text { engine oil, } \\
\text { schedule of oil change, } \\
\text { FTIR }\end{array}$ & \\
\hline
\end{tabular}

\section{Introduction}

Farm tractors are very comprehensive in comparison to other vehicles. Except for typical field and forestry works, they are also used for varied transport works or works at road maintenance (e.g. snow removal, sweeping, mowing roadsides). Therefore, they should be dependable in various climatic, weather conditions and with a varied load of the drive unit. To keep the used equipment in the best possible technical condition, it should be regularly maintained as recommended by a producer (Buchwald and Staszak, 2013).

Change of engine oil is one of the elements of technical maintenance. Engine oil during exploitation gets old and absorbs many contaminations. As a result, it loses its functions and must be subjected to periodical changes (Gomółka et al., 2011; Urzędowska and Stępień, 2012). Due to variability of the chemical composition of engine oil and variable impact of external factors on its ageing, no general schematic representation (model) of oil quality changes that took place during exploitation can be made (Źółtowski and Kastelik, 2010; Du et al., 2017; Zhu et al., 2017). Therefore, it is essential to define a moment when oil loses its functions achieving a border state of operational capability. Attempts to determine the limit state for engine oils, that are presented in literature, come down to determination of admissible changes: selected physico-chemical property of oil, parameter recognised as representative for the ageing process, set of parameters concerning property features of oil or concentration of performance chemicals. Parameters selected the most often in order to present quality changes are: kinematic viscosity in the temperature of 40 and $100^{\circ} \mathrm{C}$, nitration degree, 
oxidation and sulphanation, acid number and base number, fuel content, performance chemicals, smearity, disposition to foaming or content of elements (Woropay et al., 2006; Chmielewski, 2011; Sójka and Bukowski, 2014; Wierzcholski, 2015; Chmielewski et al., 2018; Gołębiowski et al., 2018; Raposo et al., 2019). Therefore, for correct assessment of the condition of engine oil it is indispensable for operation to obtain information on the present value of the selected assessment indicator and a threshold value of the parameter. The set of this information enables correct decision to be taken - whether the used engine oil can or cannot be used.

However, there are no cheap and simple methods of diagnosis of the condition of oils during their use. Therefore, change of engine oils in farm tractors takes place based on the determined time of exploitation of oil in an engine (a service life provided in performance hours). On one hand, it results in a not fully used oil potential, which increases the exploitation costs of tractors, on the other hand, negatively affects the natural environment, burdening it with utilization of the product that can be still used.

Tractor user's manuals provide for maintenance intervals of engine oils. Recommended dates on which engine oil should be changed depend, however, on many factors, such as: volume of oil pan, type of the used engine oil and filter, content of sulphur in engine oil, the use of biofuels, variable conditions of tractors performance and tractor maintenance. Producers provide thus, maximum times of oil use which should not be exceeded. Depending on the producer, these recommendations may be from $200-500 \mathrm{~h}$ (for brand new tractors $50 \mathrm{~h}$ ) but a change every year is recommended regardless the worked time.

According to Buchwald and Staszak (2013) a part of users of farm machines, whose guaranteed period has ended, try to extend the operational period of lubricating substances increasing also the period between technical maintenances and showing thus a trend of searching for substitutes of original exploitation elements. Such behaviour related to application of improper engine oil and/or failure to comply with the time when it should be changed, may cause premature consumption of the engine elements (Idzior and Wichtowska, 2016).

Oil change according to estimations based on the operational time of engine oil is only an estimation of the time needed for unfavourable changes to occur in the lubricating substance. Therefore, there is a threat that in extremely unfavourable conditions of exploitation, threshold values of selected parameters of oil condition e.g. viscosity, will be exceeded (Chmielewski et al., 2018).

The objective of the study was to verify whether a decision taken by tractor users on the oil change after a set time of tractor operation (h) was appropriate from the point of view of the number of exceedings of the threshold values. The paper presents results of the research of selected physico-chemical properties for engine oils after completion of the operational period, essential from the point of view of correct engine exploitation. Oils come from farm tractors with a varied age structure and varied exploitation state. Parameters were selected for analysis and assessment of operational properties of the investigated oils because they characterise the ageing process of oil that takes place during exploitation and is a basis to determine its usefulness for further exploitation (Krupowies, 2006; Chmielewski, 2017). 
Analysis of engine oils...

\section{Research methodology}

Research material consisted in used engine oils from 17 farm tractors of two producers, with a varied exploitation course. Oils were obtained from maintenance units which repair farm tractors from the region of Lubelskie Province during a standard procedure of oil change. Oils came from 3 producers and have the same viscosity class $(15 \mathrm{~W}-40)$. Characteristic of fresh oils which were used in the study was presented in table 1.

Table 1

Measured physicochemical properties of fresh engine oils

\begin{tabular}{lcccc}
\hline & & & Oil code & \\
\cline { 3 - 5 } Parameter & Unit & JD & MG & UN \\
\hline Viscosity class SAE & & & $15 \mathrm{~W} / 40$ & $\mathrm{CJ}-4$ \\
Quality class API & - & $\mathrm{CJ}-4, \mathrm{CI}-4, \mathrm{CH}-4$ & $\mathrm{CI}-4 / \mathrm{CH}-4$ & 12.79 \\
Kinematic viscosity $100^{\circ} \mathrm{C}$ & $\left(\mathrm{mm}^{2} \cdot \mathrm{s}^{-1}\right)$ & 15.53 & 13.24 & 84.74 \\
Kinematic viscosity $40^{\circ} \mathrm{C}$ & $\left(\mathrm{mm}^{2} \cdot \mathrm{s}^{-1}\right)$ & 128.27 & 85.67 & 8.42 \\
Total base number $(\mathrm{TBN})$ & $\left(\mathrm{mg} \mathrm{KOH} \cdot \mathrm{g}^{-1}\right)$ & 7.76 & 10.85 & 0.76 \\
Total Acid Number $(\mathrm{TAN})$ & $\left(\mathrm{mg} \mathrm{KOH} \cdot \mathrm{g}^{-1}\right)$ & 0.53 & 0.23 & 0.13 \\
Oxidation degree & $\left(\mathrm{Abs} \cdot 0.1 \mathrm{~mm}^{-1}\right)$ & 0.16 & 0.11 & 0.06 \\
Nitration degree & $\left(\mathrm{Abs} \cdot 0.1 \mathrm{~mm}^{-1}\right)$ & 0.07 & 0.06 & 0.16 \\
Sulfonation degree & $\left(\mathrm{Abs} \cdot 0.1 \mathrm{~mm}^{-1}\right)$ & 0.21 & 0.15 & \\
\hline
\end{tabular}

Used oils were grouped according to producers. They were marked with the following codes: JD01-04, MG01-07 and UN01-06.

When samples were taken, a general course of a tractor and time of operation of oil in a tractor were reported. Tractors with a varied age structure were selected for research and thus various technical solutions of engines and with a varied exploitation condition. Service life of oil understood as operation time of a tractor established by a producer during which safety and efficiency of operation are ensured was important from the point of view of the research. Detailed information was presented in table 2.

To determine parameters of engine oils at the end of their use, collected samples were analysed with ERASPEC OIL by Eralytics. This is a portable spectrometer from the scope of average infrared designed for measurement of physico-chemical parameters of lubricating oils which is fully compliant with the requirements of the European and American standards. The device was used for assessment of the following parameters: kinematic viscosity in $40^{\circ} \mathrm{C}$ and $100^{\circ} \mathrm{C}$, oxidation degree, nitration degree and sulfonation degree and the Total Acid Number (TAN) and Total Base Number (TBN). Those parameters were selected because they enable obtaining an image of oil degradation as a result of tractor operation. Tests were carried out based on the standard ASTM E2412-10. For all oils research in three iterations was performed and then the result was averaged:

Changes of parameters of oils collected from tractors were referred to parameters of fresh oils which were set in table 1. Moreover, values obtained for fresh oils served as a reference point for determination of threshold values. The analysis of literature showed great discrepancies in determination of threshold values of indicators of the engine oil condition. For the current assessment of the condition of oil, threshold values presented in table 3 were included. 
Wojciech Gołębiowski, Grzegorz Zając, Artur Wolak

Table 2.

Detailed info on the tractors course and oil exploitation time

\begin{tabular}{lccccc}
\hline $\begin{array}{l}\text { Code name } \\
\text { of oil }\end{array}$ & Item & Tractor model & Sample code & $\begin{array}{c}\text { Total course of } \\
\text { a tractor (h) }\end{array}$ & $\begin{array}{c}\text { Service life } \\
\text { of oil (h) }\end{array}$ \\
\hline \multirow{4}{*}{ JD } & 1 & John Deere 5090R & JD01 & 154 & 104 \\
& 2 & John Deere 5100R & JD02 & 139 & 90 \\
& 3 & John Deere 455 & JD03 & 300 & 250 \\
& 4 & John Deere 5090M & JD04 & 1019 & 300 \\
\hline \multirow{4}{*}{ MG } & 5 & New Holland T 3040 & MG01 & 50 & 50 \\
& 6 & New Holland T7.210 & MG02 & 50 & 50 \\
& 7 & New Holland TD 5.75 & MG03 & 147 & 100 \\
& 8 & New Holland T 7.AC & MG04 & 209 & 150 \\
& 9 & New Holland T 5040 & MG05 & 1360 & 300 \\
& 10 & New Holland T 6080 & MG06 & 3260 & 300 \\
UN & 11 & New Holland T 7050 & MG07 & 5527 & 300 \\
\hline 12 & New Holland T 6.165 & UN01 & 49 & 49 \\
& 13 & New Holland T 5.115 & UN02 & 56 & 56 \\
& 14 & New Holland T 5.105 & UN03 & 302 & 250 \\
& 15 & New Holland T 7.185 & UN04 & 312 & 260 \\
& 16 & New Holland T 6030D & UN05 & 612 & 250 \\
& 17 & New Holland T 6.175 & UN06 & 903 & 250 \\
\hline
\end{tabular}

Table 3.

Details related to the threshold values of parameters

\begin{tabular}{|c|c|c|c|c|c|c|}
\hline \multirow[b]{3}{*}{ Parameter } & \multirow[b]{3}{*}{ Unit } & \multicolumn{5}{|c|}{ Threshold values } \\
\hline & & \multicolumn{4}{|c|}{ referred to the branch literature } & \multirow[b]{2}{*}{$\begin{array}{c}\text { Assumed } \\
\text { in this } \\
\text { study }\end{array}$} \\
\hline & & $\begin{array}{l}\text { (Vasanthan } \\
\text { et al., 2015) }\end{array}$ & $\begin{array}{l}\text { (Kral Jr } \\
\text { et al., } \\
2014)\end{array}$ & $\begin{array}{l}\text { SAE } \\
\text { J300- } \\
2015\end{array}$ & $\begin{array}{l}\text { (Urzędowska } \\
\text { and Stępień, } \\
\text { 2012) }\end{array}$ & \\
\hline $\begin{array}{l}\text { Kinematic viscosity } \\
100^{\circ} \mathrm{C}\end{array}$ & $\left(\mathrm{mm}^{2} \cdot \mathrm{s}^{-1}\right)$ & $14.5-15.7$ & - & $\begin{array}{c}(15 \mathrm{~W})- \\
\min .11 \\
\max \\
<14,8\end{array}$ & $\pm 15 \%$ & $\pm 15 \%$ \\
\hline $\begin{array}{l}\text { Kinematic viscosity } \\
40^{\circ} \mathrm{C}\end{array}$ & $\left(\mathrm{mm}^{2} \cdot \mathrm{s}^{-1}\right)$ & - & $\pm 15 \%$ & - & $\pm 15 \%$ & $\pm 15 \%$ \\
\hline $\begin{array}{l}\text { Total Base Number } \\
(\mathrm{TBN})\end{array}$ & $\left(\mathrm{mg} \mathrm{KOH} \cdot \mathrm{g}^{-1}\right)$ & $<50 \%$ & $<30 \%$ & - & $<30 \%$ & $<50 \%$ \\
\hline $\begin{array}{l}\text { Total Acid Number } \\
\text { (TAN) }\end{array}$ & $\left(\mathrm{mg} \mathrm{KOH} \cdot \mathrm{g}^{-1}\right)$ & $\begin{array}{l}\text { In the point of } \\
\text { crossing of } \\
\text { changed lines } \\
\text { TAN and } \\
\text { TBN }\end{array}$ & - & - & $6 \mathrm{mg} \mathrm{KOH}_{1} \cdot \mathrm{g}^{-}$ & $+2,5 \mathrm{mg}$ \\
\hline Degree of oxidation & $\left(\mathrm{Abs} \cdot(0.1 \mathrm{~mm})^{-1}\right)$ & - & $>1.0$ & - & $>0.4$ & $>0.4$ \\
\hline Degree of nitration & $\left(\mathrm{Abs} \cdot(0.1 \mathrm{~mm})^{-1}\right)$ & - & $>1.0$ & - & $>0.4$ & $>0.4$ \\
\hline Degree of sulfonation & $\left(\mathrm{Abs} \cdot(0.1 \mathrm{~mm})^{-1}\right)$ & - & $>1.0$ & - & $>0.4$ & $>0.4$ \\
\hline
\end{tabular}


Analysis of engine oils...

To present the obtained results for each analysed variable, box plots were used in 3 groups that determine a type of the oil producer. The following data were included in diagrams: measured values (outliers and extremes); median and frame including a quartile range (quartile - 25 and 75 percentile).

\section{Research results}

Figure 1-7 present changes of such physico-chemical parameters as: kinematic viscosity in $40^{\circ} \mathrm{C}$ and $100^{\circ} \mathrm{C}, \mathrm{TBN}, \mathrm{TAN}$, oxidation, nitration, sulfonation referred to the threshold level of particular parameters.

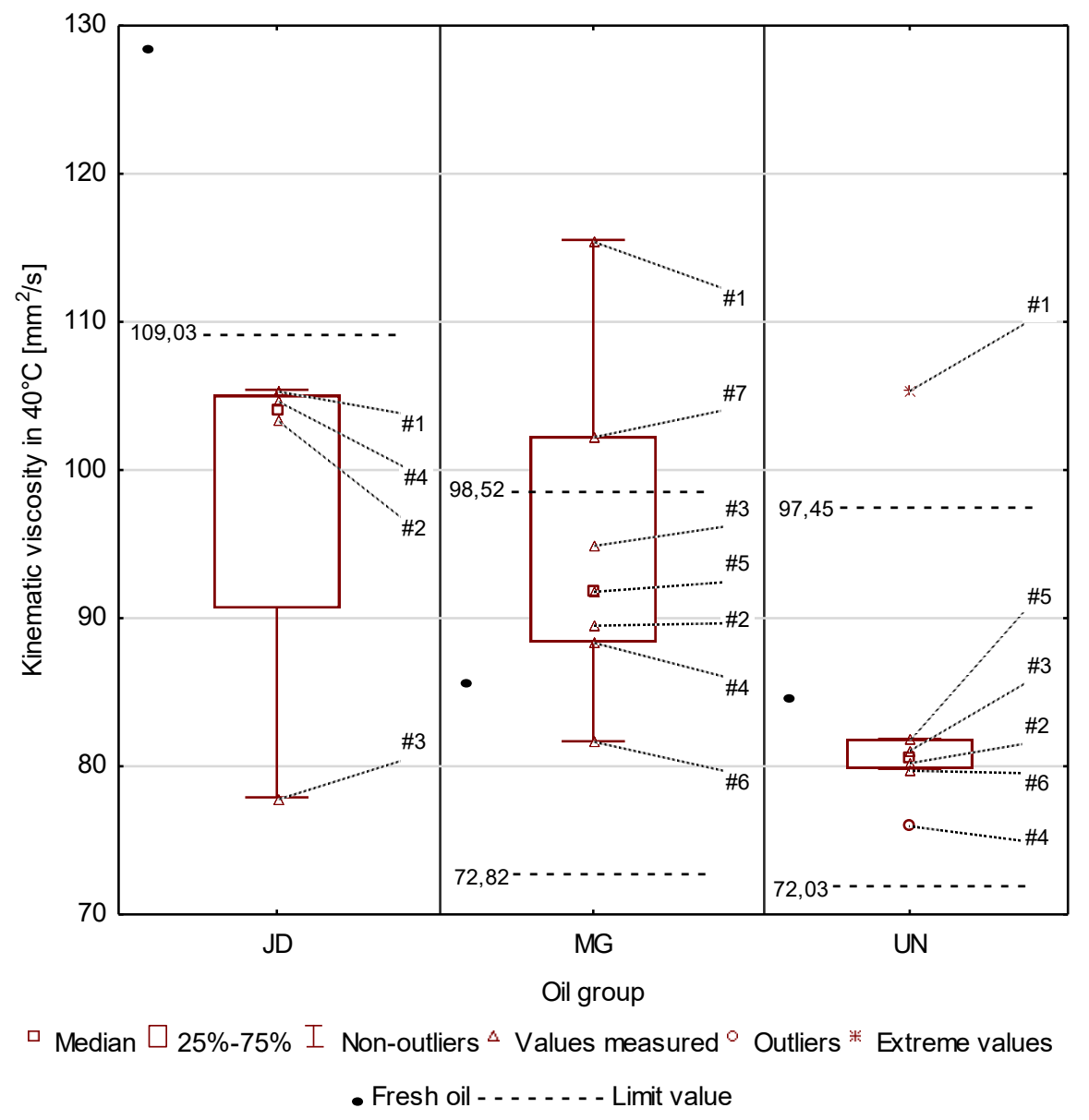

Figure 1. Kinematic viscosity in $40^{\circ} \mathrm{C}$ in tested engine oils 
In all samples from JD oil group, exceeding of threshold values for the kinematic viscosity parameter of oil in $40^{\circ} \mathrm{C}$ was reported. Exceeding of the bottom threshold value is visible which may lead to the lack of protection of friction mechanisms. In two samples from MG oil group (one after 50 hours of operation and the second one after $300 \mathrm{~h}$ ) exceeding of the maximum limit of the viscosity value was observed which may be a basis for elimination of oil from further exploitation due to considerable impediment in oil distribution and as a result possibility of not sufficient lubrication of moving parts of the mechanism. It should be said that exceeding the threshold values did not affect the time of oil use in particular tractors (example of oils from JD group) in the oil sample JD01 after $100 \mathrm{~h}$ and in sample JD04 after $400 \mathrm{~h}$ identical exceeding by $18 \%$ in comparison to the value of fresh oil was reported).

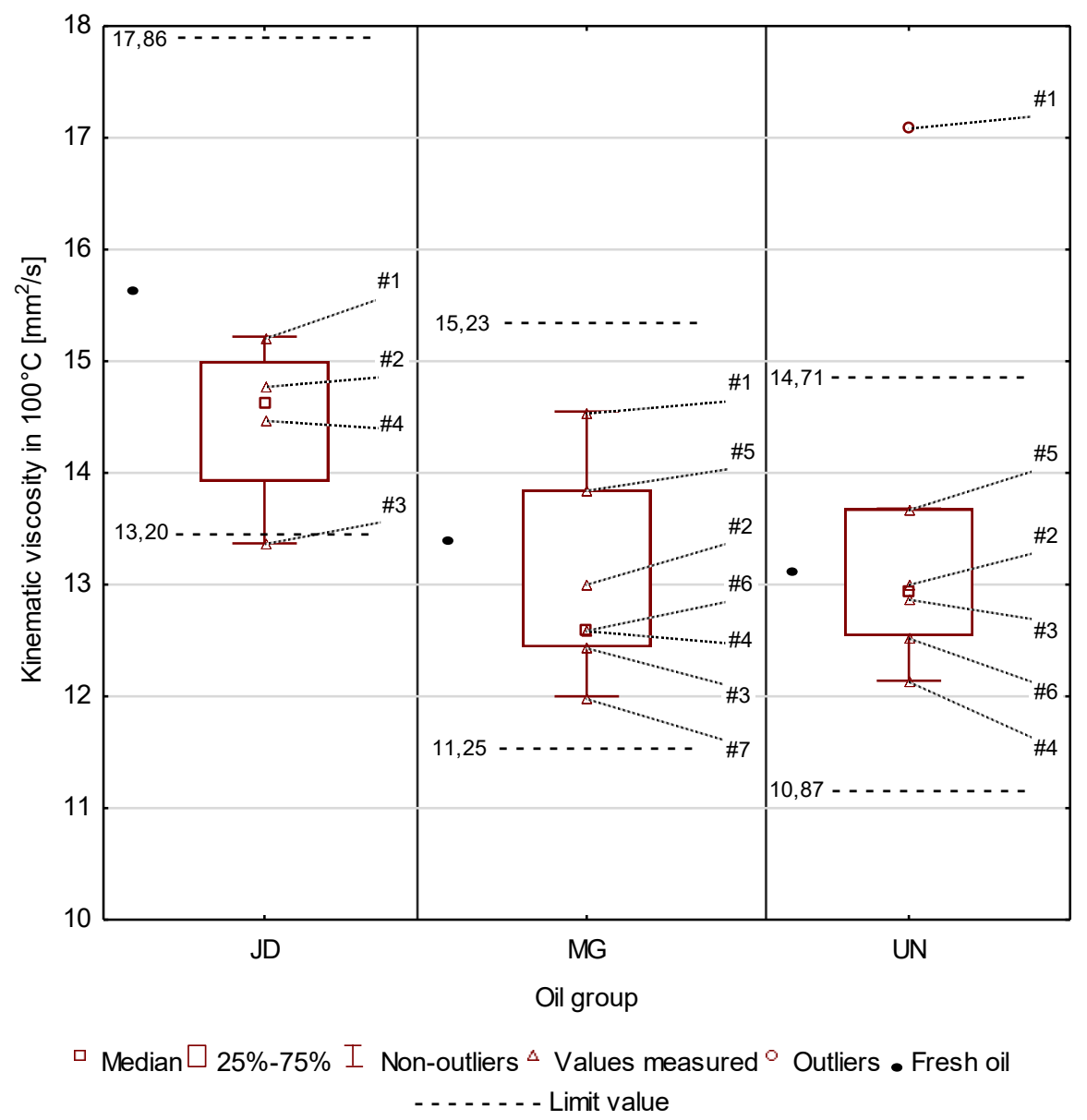

Figure 2. Kinematic viscosity in $100^{\circ} \mathrm{C}$ in tested engine oils 
Analysis of engine oils...

The diagram from figure 2 shows that kinematic viscosity in $100^{\circ} \mathrm{C}$, in a decisive number of oil samples (16/17) was within the determined limits which proves that oil still met the criteria of a given parameter. One sample of oil exceeded the maximum value of a parameter, it was sample UN01 after 49 hours of operation (increase by $34 \%$ in comparison to fresh oil). This sample differed from the remaining set of a given oil group and was recognised as a diverging sample. A reason for exceeding the determined thresholds was a high content of carbon black. Such oil may characterise with impeded distribution on the surface of cooperating engine parts.

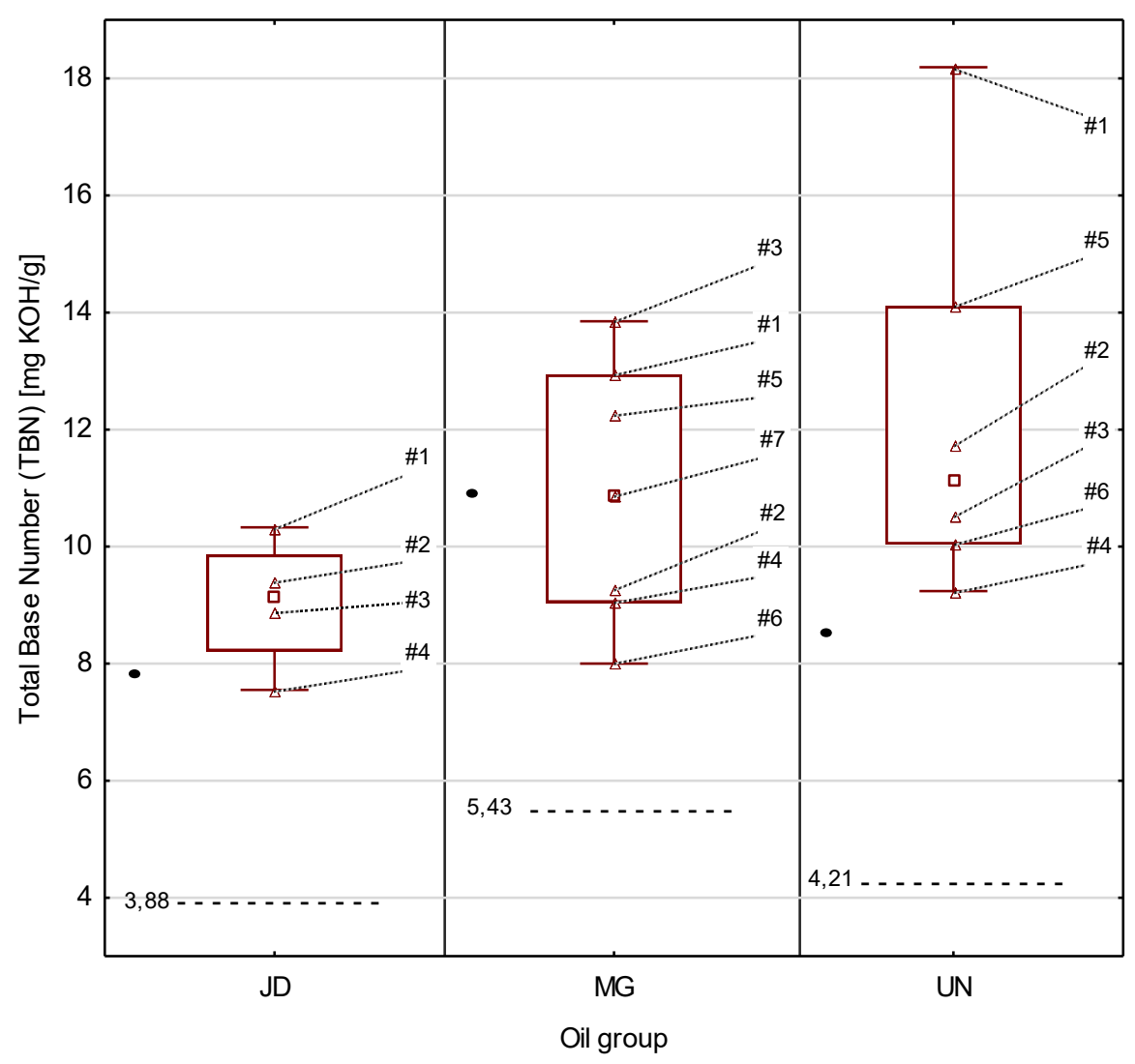

口 Median $\square$ 25\%-75\% I Non-outliers ${ }^{\Delta}$ Values measured • Fresh oil - . . . . - - Limit value

Figure 3. Total base number in tested engine oils 
Another investigated parameter was the Total Base Number (TBN) and the total Acid Number (TAN). Results of determination of the base number in analysed oils is presented in figure 3. All samples of oil were within the determined thresholds and did not fall below the accepted minimum threshold values. No increased loss of TBN was observed with reference to the oil operation period. Both the oil courses 300,100 and $50 \mathrm{~h}$ had similar TBN losses ca. $15 \%$.

Analysis of the results of TAN in tested oils shows that with reference to all analysed samples the threshold value is not exceeded. It is worth mentioning that oils after the exploitation period, which is $300,500 \mathrm{~h}$ are not inclined to exceed the critical value of TAN. Results of determination of the acid number in analysed oils is presented in figure 4.

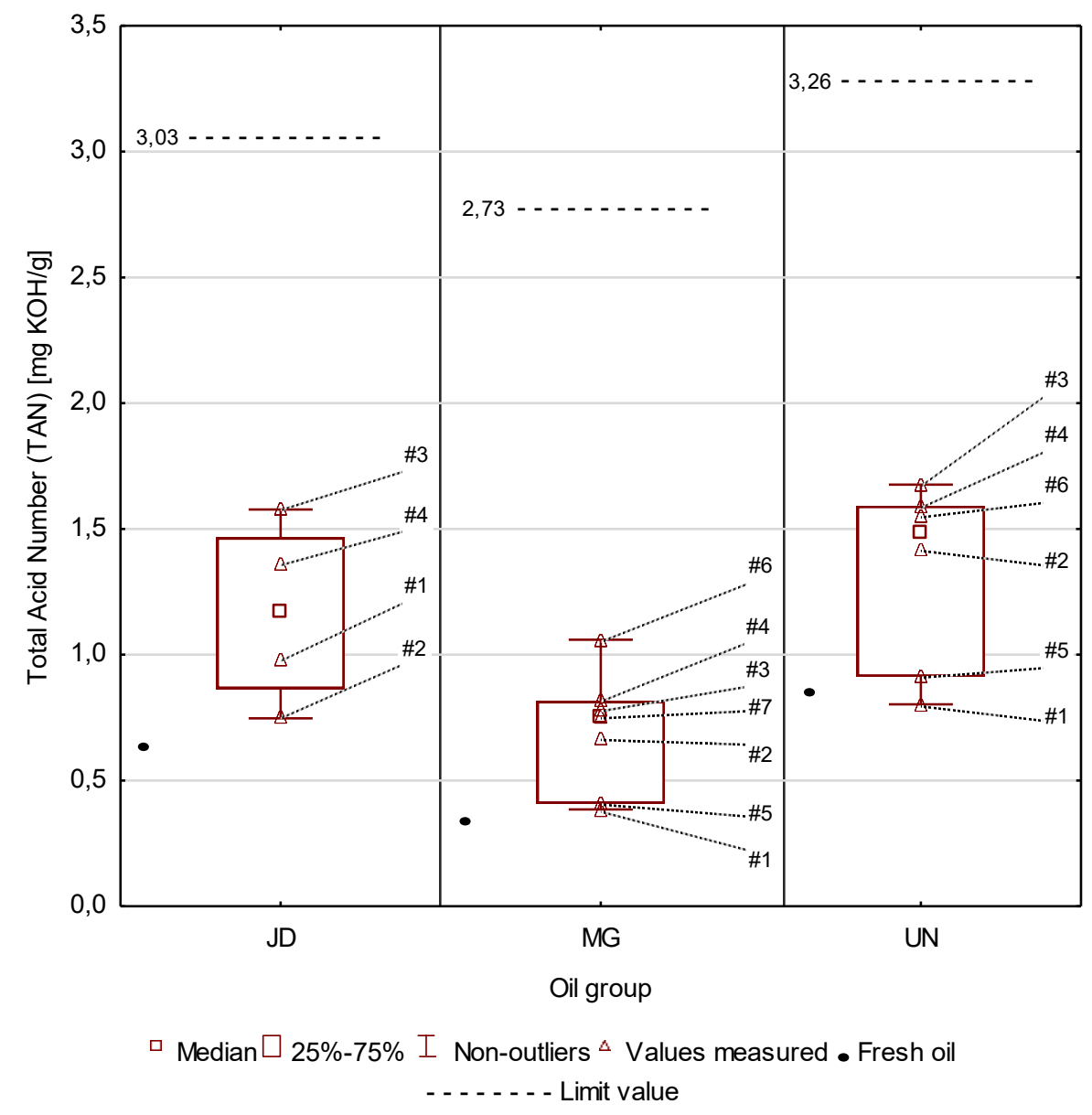

Figure 4. Total Acid Number in tested engine oils 
Analysis of engine oils...

In no analysed oil the assumed critical value of oxidation which was $0.4 \mathrm{Abs} \cdot 0.1 \mathrm{~mm}^{-1}$ was exceeded. The highest oxidation degree was reported in the group of JD oil with a symbol JD05 $(300 \mathrm{~h})$, which was $0.177 \mathrm{Abs} \cdot 0.1 \mathrm{~mm}^{-1}$. While, the highest value was observed in the group of MG oil, in which sample MG01 $(50 \mathrm{~h})$ showed the value of this parameter at the level of $0.114 \mathrm{Abs} \cdot 0.1 \mathrm{~mm}^{-1}$. Oxidation degree of oil in investigated samples was presented in figure 5.

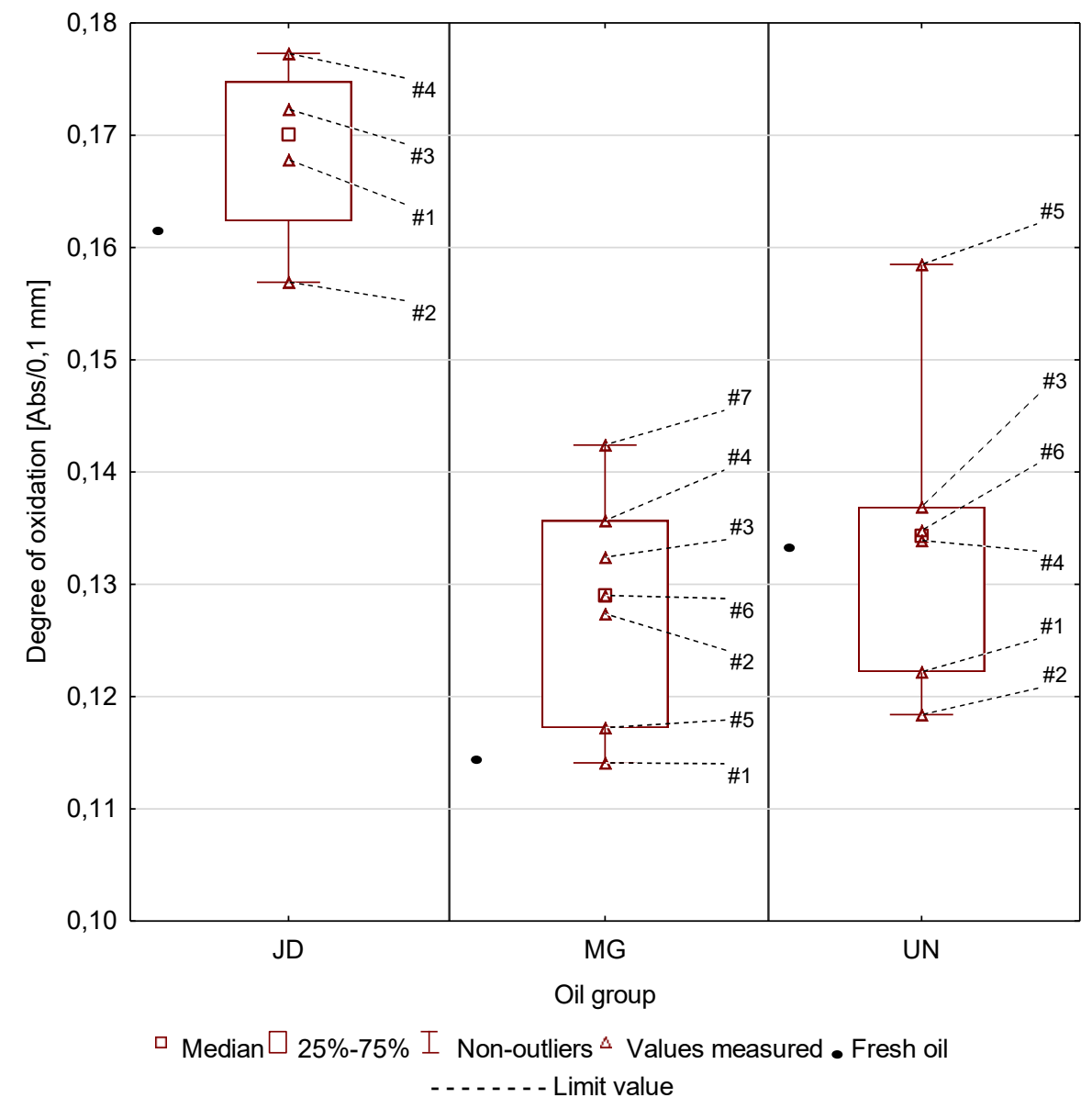

Figure 5. Oxidation degree in tested engine oils 
The assumed threshold value of nitration of $0.4 \mathrm{Abs} \cdot 0.1 \mathrm{~mm}^{-1}$ was not exceeded in any of the analysed samples. While, the highest value was observed in the group of UN oil, in which sample UN02 after the extended amount period of $56 \mathrm{~h}$ showed the value of this parameter at the level of $0.060 \mathrm{Abs} \cdot 0.1 \mathrm{~mm}^{-1}$. Such a low level could have been reached by adding fresh oil to engine. The highest nitration degree was observed in the group of JD oil in the oil sample JD03 $\left(0.106\right.$ Abs $\left.\cdot 0.1 \mathrm{~mm}^{-1}\right)$, which was obtained from a tractor after exploitation course of oil which was $250 \mathrm{~h}$. The nitration degree of oils was presented in fig.6.

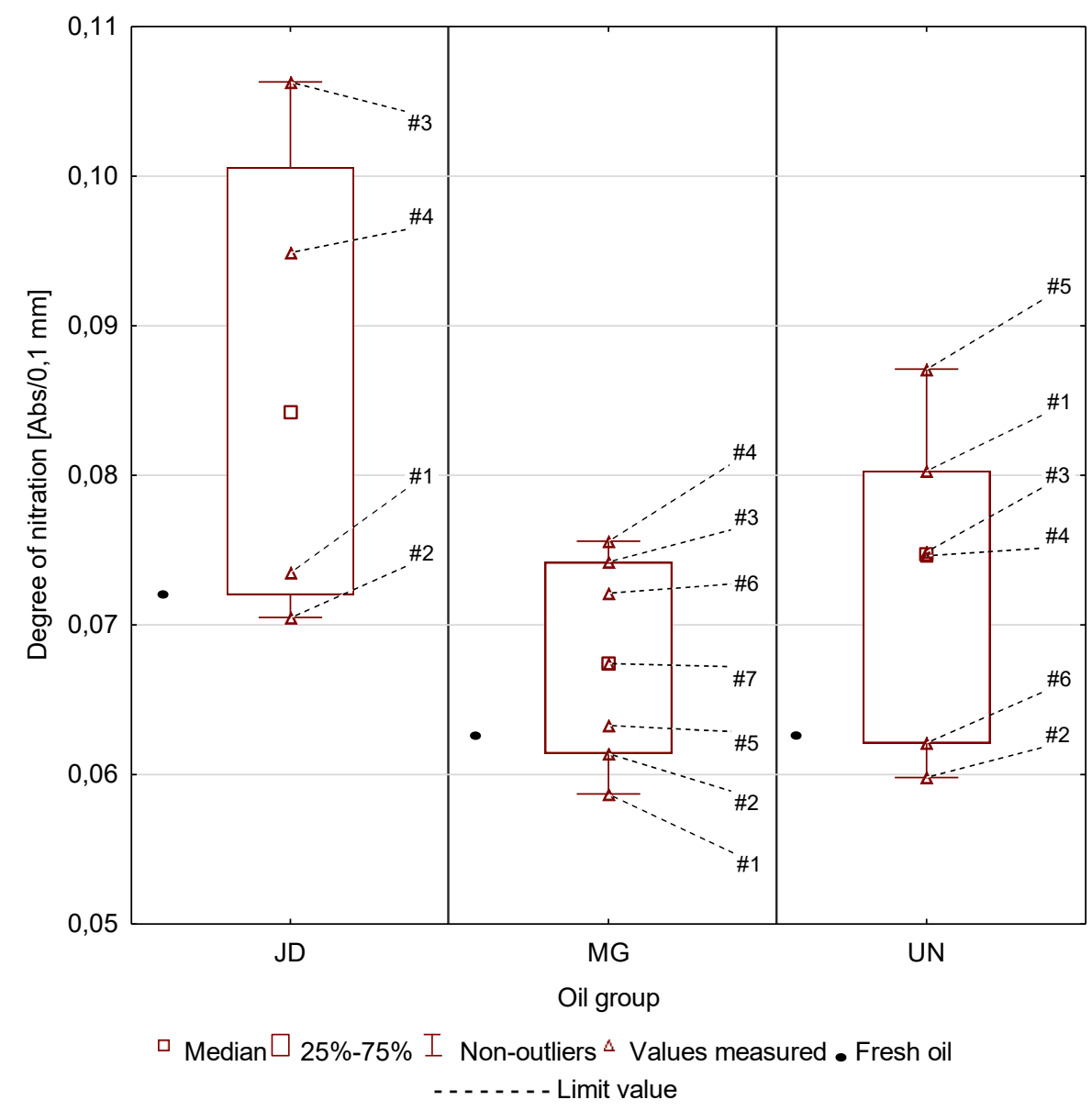

Figure 6. Nitration degree in tested engine oils 
Analysis of engine oils...

The assumed threshold value of sulfonation was not exceeded in any of the tested samples. The highest value was reported in the group of JD oil with a symbol JD03 $(250 \mathrm{~h})$, which was $0.273 \mathrm{Abs} \cdot 0.1 \mathrm{~mm}^{-1}$. While, the highest value was observed in the group of MG oil, in which sample MG05 $(300 \mathrm{~h})$ showed the value of this parameter at the level of 0.154 Abs $/ 0.1 \mathrm{~mm}$. The results of the sulfonation degree were presented in figure 7 .

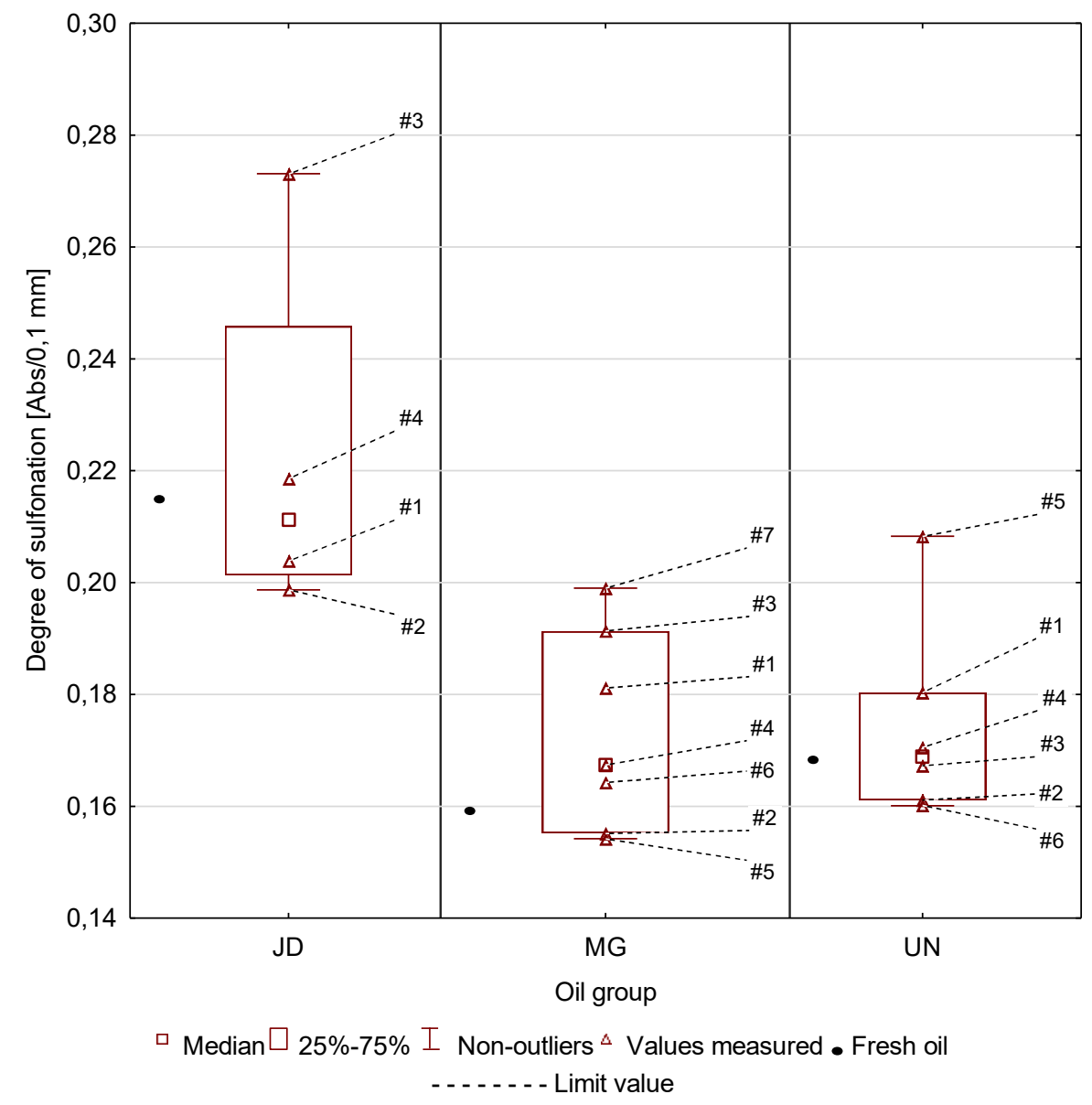

Figure 7. Sulfonation degree in tested engine oils

Results of the tests of particular oil parameters for all investigated groups were presented in table 4 . The highest number of exccedings was reported for the kinematic viscosity of oil in $40^{\circ} \mathrm{C}$. Moreover, one sample exceeded the determined threshold value for oil viscosity in $100^{\circ} \mathrm{C}$. No exceedings for such oil parameters as acid number, base number, oxidation degree, nitration and sulfonation degree were reported. The research results are surprising 
because the highest number of exceedings, namely 2 out of 7 possible were reported for oil sample from a tractor with a relatively small exploitation course of oil that is $49 \mathrm{~h}$ and not like it was expected for tractors with a much longer service life of oil. This example may constitute additional confirmation of the fact that we should pay much greater attention to an individual character of the tractor operation.

\section{Conclusion}

Values of engine oil parameters (both of fresh oil and measured during engine operation) are not uniform and change in relation to operation conditions, time of operation, technical condition of an engine or its components. Any changes of properties of engine lubricants that exceed threshold upper and lower ranges accepted for them, bring negative effects in the form of possible faults (Idzior and Wichtowska, 2016). The condition of oil is compared to the condition of fresh oil and refers to the threshold values which should not be exceeded. If any value achieves a limit state, it means that oil does not meet its full functions and should be changed.

The tests that were performed enabled determination of distribution of frequency of the threshold values for determined parameters of the investigated engine oil. In selected oils, from among all determined parameters, only exceeding of kinematic viscosity in $40^{\circ} \mathrm{C}(41 \%)$ and $100^{\circ} \mathrm{C}(6 \%)$ was reported. Wolak and Zając (Wolak and Zajac, 2017) in their studies showed that the results obtained by means of spectrometers operating in infrared (units that were initially set up with those already uploaded in data bases) should be accepted with caution. Methods used in specialist laboratories not always can confirm them. Such units have similar trends and dynamics of changes of the analysed parameters, they can both increase or decrease the results.

With reference to ten samples of oil, no exceeding was reported, thus the change took place too early. In six cases after one exceeding, it was concluded that the moment of change was similar to optimal. In one case (UN01 (time of operation 49 h)/ New Holland T 6.165), more than one case of exceeding was reported. Therefore, assuming that exceeding of at least one parameter is a criterion for oil changes, it should be considered that a half of the investigated engine oils was changed after the critical value was exceeded. However, when we are guided with the size of those exceedings and a parameter which was exceeded, the assessment does not seem to be explicit any more. Slight deviations may only be the basis for further control of the condition of oil.

The presented studies should be considered as pilot that aim at showing the problem related to determination of the date when oil should be changed. It should be said that extending the survey with a higher number of vehicles and analysed parameters and analysis of the nature of tractor operation would enable verification of standards for oil change suggested by producers. 
Analysis of engine oils...

\section{References}

Buchwald, T., Staszak, Ż. (2013). Analiza realizacji przeglądów technicznych ciągników rolniczych. Inżynieria Rolnicza, 3(146), 47-55.

Chmielewski, Z. (2011). Cykliczność wymiany oleju w silniku spalinowym w aspekcie procesu zużywania tulei cylindrowych. Silniki Spalinowe, 50(3), 1-5.

Chmielewski, Z. (2017). Stany niezawodnościowe oleju silnikowego w eksploatacji. Autobusy Technika, Eksploatacja, Systemy Transportowe, 12, 761-764.

Chmielewski, Z., Stobiecki, J., Górska, M. (2018). Koncepcja oceny niezawodności współczesnych olejów silnikowych w eksploatacji. Autobusy - Technika, Eksploatacja, Systemy Transportowe, 12, 337-340.

Du, Y., Wu, T., Makis, V. (2017). Parameter estimation and remaining useful life prediction of lubricating oil with HMM. Wear, 376-377, 1227-1233.

Gołębiowski, W., Wolak, A., Zając, G. (2018). Definition of oil change intervals based on the analysis of selected physicochemical properties of used engine oils. Combustion Engines, 57, 44-50.

Gomółka, L., Augustynowicz, A., Maciąg, A. (2011). Analiza stopnia degradacji oleju smarującego w silnikach spalinowych. Silniki Spalinowe 50(3), 10-14.

Idzior, M., Wichtowska, K. (2016). Badanie wpływu przebiegu pojazdów na zmiany właściwości olejów silnikowych. Autobusy - Technika, Eksploatacja, Systemy Transportowe, 17, 900-904.

Kral Jr, J., Konecny, B., Kral, J., Madac, K., Fedorko, G., Molnar, V. (2014). Degradation and chemical change of longlife oils following intensive use in automobile engines. Measurement 50, 34-42.

Krupowies, J. (2006). Analiza zmian właściwości użytkowych olejów smarowych firmy BP w czasie ich eksploatacji. Zeszyty Naukowe Akademia. Morska w Szczecinie, 10(82), 309-318.

Raposo, H., Farinha, J. T., Fonseca, I., Ferreira, L. A. (2019). Condition Monitoring with Prediction Based on Diesel Engine Oil Analysis: A Case Study for Urban Buses. Actuators 8(1), 14.

Sójka, M., Bukowski, P. (2014). Analiza możliwości wydłużenia resursu olejów silnikowych w pojazdach szynowych. Logistyka, 6, 14773-14780.

Urzędowska, W., Stępień, Z. (2012). Wybrane zagadnienia dotyczące zmian właściwości silnikowego oleju smarowego w eksploatacji. Nafta-Gaz, 12, 1102-1110.

Vasanthan, B., Devaradjane, G., Shanmugam, V. (2015). Online condition monitoring of lubricating oil on test bench diesel engine \& vehicle. Journal of Chemical and Pharmaceutical Sciences, 9, 315-320.

Wierzcholski, K. (2015). Charakterystyki resursu olejów dla smarowanych połączeń tarciowych. Tribologia, 1, 137-148.

Wolak, A., Zajac, G. (2017). Changes in the operating characteristics of engine oils: a comparison of the results obtained with the use of two automatic devices. Measurement, 113C, 53-61.

Woropay, M., Bukowski, P., Sójka, M. (2006). Zmiany własności fizyko-chemicznych olejów silnikowych jako parametr diagnostyczny. Diagnostyka, 4(40),157-162.

Zhu, X., Zhong, C., Zhe, J. (2017). Lubricating oil conditioning sensors for online machine health monitoring - A review. Tribology International, 109, 473-484.

Żółtowski, B., Kastelik, M. (2010). Application of spectroscopic research methods for motor oil condition and quality evaluation. Journal of Polish CIMAC, 5(1), 213-219. 
Wojciech Gołębiowski, Grzegorz Zając, Artur Wolak

\section{ANALIZA OLEJÓW SILNIKOWYCH POCHODZĄCYCH Z CIĄGNIKÓW ROLNICZYCH W ASPEKCIE TERMINU ICH WYMIANY}

Streszczenie. W pracy przedstawiono wyniki badań wybranych parametrów fizykochemicznych olejów silnikowych pochodzących z ciągników rolniczych, bazując na terminie wymiany oleju przyjętym przez użytkownika ciągnika. Analizie poddano 17 próbek przepracowanego oleju silnikowego, pochodzących z ciągników rolniczych różnych producentów i o różnym przebiegu eksploatacyjnym. Oleje do badań pobrano podczas wymiany oleju, każdorazowo rejestrując resurs oleju. Pozyskano je z serwisów zajmujących się naprawami ciągników rolniczych z terenu woj. lubelskiego. Przeprowadzone badania miały na celu sprawdzenie, czy podjęta przez użytkowników ciągników decyzja o wymianie oleju po określonym czasie pracy silnika, była właściwa. Ocenę przeprowadzono $\mathrm{w}$ oparciu o analizę liczby przekroczeń wartości granicznych parametrów, odpowiadających za zdolność oleju silnikowego do prawidłowego smarowania.

Słowa kluczowe: olej silnikowy, harmonogram wymiany oleju, FTIR

Identification data Authors:

Wojciech Golębiowski https://orcid.org/0000-0002-4170-1351

Grzegorz Zając https://orcid.org/0000-0002-9025-4551

Artur Wolak https://orcid.org/0000-0003-4145-8862 